$\begin{array}{llllllllllllllll}\mathbf{S} & \mathbf{T} & \mathbf{U} & \mathbf{D} & \mathbf{I} & \mathbf{A} & \mathbf{I} & \mathbf{M} & \boldsymbol{A} & \mathbf{T} & \mathbf{E} & \mathbf{R} & \mathbf{I} & \mathbf{A} & \mathbf{E} & \mathbf{Y}\end{array}$

A R C H I W A, B I B L I O T E K I

I MUZEA KOŚCIELNE 104 (2015)

ARTUR HAMRYSZCZAK* - LUBLIN

\title{
KS. PROF. MAREK TOMASZ ZAHAJKIEWICZ (1934-2015) - DYREKTOR OŚRODKA ARCHIWÓW BIBLIOTEK I MUZEÓW KOŚCIELNYCH KUL
}

Marek Tomasz Zahajkiewicz urodził się 18 lutego 1934 roku w Borysławiu (województwo lwowskie), w rodzinie Stanisława, urzędnika Polskich Kolei Państwowych i Marii z domu Ficoń. Dzieciństwo, w tym lata drugiej wojny światowej, spędził w Stryju. W 1945 roku został ekspatriowany wraz z rodzicami do Chełma. Tutaj ukończył szkołę podstawową, a następnie I Liceum Ogólnokształcące im. Stefana Czarnieckiego, gdzie w 1951 roku zdał maturę. W tym też roku wstąpił do Seminarium Duchownego w Lublinie, stając się równocześnie studentem Katolickiego Uniwersytetu Lubelskiego. Święcenia kapłańskie przyjął w 1956 roku. Po ukończeniu seminarium, rozpoczął studia specjalistyczne w zakresie historii Kościoła na Wydziale Teologii KUL. W latach 1957-1959, ze względu na konieczność nauczania religii w szkołach państwowych, przerwał studia. W 1962 roku uzyskał magisterium na podstawie pracy napisanej pod kierunkiem ks. prof. Mariana Rechowicza Liturgia mszy świętej w świetle ,, Tractatus sacerdotalis" Mikołaja z Błonia. Od 1965 roku rozpoczął pracę w Katedrze Liturgii na Wydziale Teologii KUL. W 1967 roku otrzymał doktorat na podstawie dysertacji Msza święta w Polsce do Soboru Trydenckiego w świetle rodzimych komentarzy (Expositiones missae). Studium historyczno-liturgiczne, napisanej na seminarium ks. prof. M. Rechowicza. W tym samym roku rozpoczął pracę w Katedrze Historii Kościoła w Średniowieczu na Wydziale Teologii. W 1976 roku na podstawie dorobku naukowego i rozprawy „, Tractaus sacerdotalis” Mikołaja z Błonia na tle teologii przełomu wieku XIV i XV, Rada Wydziału Teologii nadała mu tytuł doktora habilitowanego teologii w zakresie historii Kościoła. W 1991 roku otrzymał tytuł naukowy profesora.

W swojej pracy naukowej koncentrował się na zagadnieniach dotyczących reformy Kościoła w średniowieczu, dziejów liturgii, teologii średniowiecznej, średniowiecznych misji polskich, badał również historię diecezji lubelskiej.

\footnotetext{
* Artur Hamryszczak - dr historii, asystent naukowy w Ośrodku Archiwów Bibliotek i Muzeów Kościelnych KUL, e-mail: artur.hamryszczak@kul.pl
} 
Ks. M. Zahajkiewicz jako samodzielny pracownik naukowy prowadził seminarium naukowe z zakresu historii Kościoła. Pod jego kierunkiem napisano 149 prac magisterskich i trzy licencjackie. Ks. M. Zahajkiewicz wypromował również siedmiu doktorów, wśród których było trzech pracowników Ośrodka Archiwów Bibliotek i Muzeów Kościelnych KUL (redakcji półrocznika „Archiwa Biblioteki i Muzea Kościelne"): ks. Stanisław Tylus - Edycja krytyczna i analiza dokumentów fundacyjnych parafii średniowiecznej archidiecezji lwowskiej (1998), Ryszard Skrzyniarz - „Kazania świętokrzyskie” jako świadectwo kerygmy średniowiecznego Kościoła polskiego (1998), ks. Włodzimierz Bielak - Wpływ „,devotio moderna" na wybrane podręczniki dla duchowieństwa powstałe $w$ środowisku Uniwersytetu Krakowskiego w 1. połowie XV wieku (2000).

Bardzo aktywnie brał udział ks. prof. M. Zahajkiewicz w sympozjach naukowych, krajowych i zagranicznych, na których wygłosił 65 referatów, które w głównej mierze dotyczyły historii Kościoła w średniowieczu. Był również członkiem towarzystw naukowych: Towarzystwa Naukowego KUL, Lubelskiego Towarzystwa Naukowego, Polskiego Towarzystwa Teologicznego oraz Komisji Historycznej Oddziału PAN w Lublinie.

W Katolickim Uniwersytecie Lubelskim pełnił ks. M. Zahajkiewicz kilka funkcji administracyjnych. W latach 1978-2006 był kierownikiem Katedry Historii Kościoła w Średniowieczu, zaś w okresie 1983-2004 kierował Instytutem Historii Kościoła na Wydziale Teologii KUL. Był również członkiem Komisji Episkopatu Polski do Spraw Sztuki Kościelnej (1987-2006). Od 1989 roku był pełnomocnikiem Rektora do spraw odzyskania nieruchomości utraconych przez KUL w czasach PRL. Natomiast od 1992 r. był przewodniczącym Komisji Rewizyjnej Fundacji Potulickiej w Wojnowie.

W 1985 roku ks. M. Zahajkiewicz objął funkcję dyrektora Ośrodka Archiwów Bibliotek i Muzeów Kościelnych KUL, którą pełnił do 2006 roku. W czasie swojego kierowania Ośrodkiem zorganizował 20 sesji naukowych z archiwistyki, bibliotekarstwa i muzealnictwa kościelnego: Aktualne problemy muzealnictwa kościelnego w Polsce (1986), Podstawowe procesy biblioteczne (1987), Konserwacja obiektów sztuki sakralnej (1988), Problemy konserwacji kościelnych zasobów archiwalnych (1989), Problemy konserwacji kościelnych zbiorów bibliotecznych (1990), Gromadzenie i ksztaltowanie zasobu w archiwach kościelnych (1991), Organizacja procesów gromadzenia zbiorów w bibliotekach kościelnych (1992), Gromadzenie zbiorów jako funkcja muzeum kościelnego (1993), Kancelaria i archiwum kościelne (1994), Opracowywanie zbiorów w bibliotekach kościelnych w Polsce (1995), Opracowanie zbiorów w muzeach kościelnych w Polsce (1996), Komputeryzacja archiwów kościelnych w Polsce (1997), Opracowanie rzeczowe zbiorów bibliotecznych (1998), Problemy archiwów parafialnych i klasztornych (2000), Problemy bibliotek parafialnych i klasztornych (2001), Znaczenie muzeów parafialnych i klasztornych (2002), Informacja i udostępnianie zasobów $w$ archiwach Kościoła Katolickiego w Polsce (2003), Funkcje i zadania bibliotek kościelnych (2004), Muzea kościelne w 100-lecie działalności (2005). Ostatnia sesja zorganizowana przez ks. M. Zahajkiewicza: Troska o dziedzictwo kulturowe Kościoła. 50-lecie Ośrodka Archiwów Bibliotek i Muzeów Kościelnych (2006) 
miała charakter podsumowujący działalność Ośrodka ABMK w ostatnim półwieczu oraz była pożegnaniem dotychczasowego dyrektora. Należy wspomnieć, że na wspomnianych konferencjach naukowych, ks. M. Zahajkiewicz brał czynny udział i wygłaszał referaty.

W czasie jego kierownictwa, Ośrodek ABMK wypełniał swoje zadania statutowe, nie tylko przez organizowanie sesji naukowych, ale i prowadząc badania naukowe. Do najważniejszych osiągnięć tego okresu należy zaliczyć nawiązanie współpracy w 1995 roku z klasztorem norbertanek w Imbramowicach k. Olkusza. Pracownicy Ośrodka ABMK zinwentaryzowali, opracowali i skatalogowali zbiory kulturowe konwentu: archiwalne, biblioteczne i muzealne. Archiwum klasztoru zostało uporządkowane, a najcenniejsza dokumentacja zmikrofilmowana. Skatalogowano również zbiory biblioteczne oraz zmikrofilmowano wybrane druki. Dwie najcenniejsze rękopiśmienne księgi: antyfonarz z XIII wieku i graduał z 1343 roku zostały z inicjatywy Ośrodka ABMK, poddane renowacji. Dodatkowo zinwentaryzowano zbiory muzealne klasztoru. Podobnie opracowany został księgozbiór bożogrobców z Miechowa. Rozpoczęto również systematyczne opracowywanie archiwaliów z diecezji łuckiej, które po drugiej wojnie światowej przewieziono do Polski, a w latach 80 . XX wieku znalazły swoje miejsce w Ośrodku ABMK.

Ks. M. Zahajkiewicz zwracał dużą uwagę na mikrofilmowanie w Ośrodku ABMK archiwaliów i cennych starodruków o kościelnej proweniencji. Do szczególnie ważnych zmikrofilmowanych akt należą m.in. wizytacje kanoniczne z diecezji: włocławskiej, płockiej, poznańskiej, gnieźnieńskiej, chełmińskiej i pomezańskiej. Kontynuowano również mikrofilmowanie dokumentacji z archiwum lwowskiego, przechowywanego w Archiwum Abpa Baziaka w Krakowie (aktualnie w strukturach Uniwersytetu Papieskiego Jana Pawła II w Krakowie).

W 2002 roku roku Ośrodek ABMK rozpoczął wydawanie serii Biblioteka Ośrodka Archiwów Bibliotek i Muzeów Kościelnych. W jej ramach wyszły informatory o archiwach, bibliotekach i muzeach Kościoła katolickiego w Polsce, wykazy z akt metrykalnych diecezji łuckiej i pińskiej, wydawnictwa źródłowe, monografie parafii itp.

Organem wydawniczym Ośrodka ABMK jest półrocznik „Archiwa Biblioteki i Muzea Kościelne”, którego przewodniczącym Rady Naukowej był przez wiele lat ks. prof. M. Zahajkiewicz. W czasie pełnienia swojej funkcji czuwał nad poziomem naukowym pisma, będąc ostatnią instancją w trudnych sprawach oraz decydował również o zatrudnianiu redaktorów pisma. Po odejściu ks. S. Librowskiego z funkcji redaktora naczelnego, zaangażował ks. Stanisława Tylusa, który objął kierownictwo po ks. Joachimie Gieli w 1993 r. i wydał tomy 63 (1993) - 74 (2000). W 2001 r. kierownictwo pisma objął ks. W. Bielak. Pierwszym tomem pod jego kierownictwem był numer 75 (2001), a ostatnim - 98 (2012). W latach 19952005 redaktorem półrocznika był Ryszard Skrzyniarz, a po nim pracę w piśmie podjął Artur Hamryszczak.

Oczywiście ks. M. Zahajkiewicz odpowiadał za politykę kadrową całego Ośrodka, zatrudniając pracowników o odpowiednich kwalifikacjach, niezbędnych do pracy w kierownej przez niego placówce. W 1995 roku przyjął od pracy ks. 
Waldemara Żurka, w 2002 roku - Artura Hamryszczaka, a w 2005 roku - Daniela Kipera.

Zwieńczeniem pracy ks. prof. Marka Zahajkiewicza nie tylko w Ośrodku ABMK, ale i w Katolickim Uniwersytecie Lubelskim Jana Pawła II było uroczyste wręczenie mu księgi pamiątkowej Historia świadectwem czasów w dniu 29 września 2006 r. Księga została przygotowana przez uczniów, współpracowników, kolegów i przyjaciół oraz władze Uniwersytetu, jako wyraz wdzięczności i podziękowania za długoletnią pracę w KUL. Jubileusz miał podwójny wymiar dla ks. M. Zahajkiewicza, bowiem przypadało wówczas 50-lecie jego święceń kapłańskich i 50-lecie pracy dydaktycznej w KUL.

Ks. M. Zahajkiewicz zmarł w Lublinie 25 lipca 2015 roku. Uroczystości pogrzebowe odbyły sie 29 lipca. Msza św. żałobna została odprawiona w archikatedrze lubelskiej, a msza św. pogrzebowa w kościele pw. Rozesłania św. Apostołów w Chełmie, gdzie ks. prof. spocząl na cmentarzu przy ulicy Wojsławickiej.

Podsumowaniem życia i działalności ks. M. Zahajkiewicza są słowa abpa Stanisława Wielgusa, które wygłosił podczas mszy św. żałobnej:

Ksiądz prof. Marek Zahajkiewicz był [...] ważną osobą - znacząco oddziałał na historię KUL i na życie wielu ludzi, z którymi spotykał się jako profesor, jako kapłan i jako ogromnie życzliwy mistrz, wychowawca, wykładowca i przyjaciel.

słowa kluczowe: ks. Marek T. Zahajkiewicz, Ośrodek Archiwów Bibliotek i Muzeów Kościelnych, półrocznik „Archiwa Biblioteki i Muzea Kościelne”, przewodniczący Rady Naukowej, dyrektor Ośrodka ABMK, Katolicki Uniwersytet Lubelski Jana Pawła II 


\section{BIBLIOGRAFIA}

Dębowska Maria, Archiwum norbertanek w Imbramowicach, „Archiwa Biblioteki i Muzea Kościelne", 94 (2010) s. 29-38.

Dębowska Maria, Katalog mikrofilmów Ośrodka Archiwów, Bibliotek i Muzeów Kościelnych przy Katolickim Uniwersytecie Lubelskim Nr 6, „Archiwa Biblioteki i Muzea Kościelne", 67 (1997) s. 143-220.

Dębowska Maria, Katalog mikrofilmów Ośrodka Archiwów Bibliotek i Muzeów Kościelnych Katolickiego Uniwersytetu Lubelskiego. Nr 7, „Archiwa Biblioteki i Muzea Kościelne", 84 (2005) s. 5-72.

Dębowska Maria, Ośrodek Archiwów Bibliotek i Muzeów Kościelnych Katolickiego Uniwersytetu Lubelskiego Jana Pawła II 1956-2006, Lublin 2006.

Dębowska Maria, Skrzyniarz Ryszard, Zasoby archiwalne zakonu bożogrobców w archiwum parafialnym w Miechowie, „Archiwa Biblioteki i Muzea Kościelne”, 86 (2007) s. 83-106.

Hamryszczak Artur, Historia świadectwem czasów. Jubileusz Ks. Prof. Dr. Hab. Marka T. Zahajkiewicza, „Archiwa Biblioteki i Muzea Kościelne”, 87 (2007) s. 395-399.

Hamryszczak Artur, Ochrona kościelnych dóbr kultury na przykładzie Klasztoru Norbertanek w Imbramowicach, w: Między teorią a praktyką. Ochrona zbiorów w małych bibliotekach i archiwach. Materiały z konferencji naukowej Cieszyn 3-5 marca 2010 r., red. A. Czajka, R. Lis, Cieszyn 2010, s. 337-375.

Hamryszczak Artur, Półrocznik „Archiwa Biblioteki i Muzea Kościelne”. Przeszłość-teraźniejszość-przyszłość, „Archiwa Biblioteki i Muzea Kościelne”, 100 (2013) s. 5-16.

Hamryszczak Artur, Prace Ośrodka Archiwów Bibliotek i Muzeów Kościelnych w zakresie dokumentowania zbiorów bibliotek klasztornych, „Archiwa Biblioteki i Muzea Kościelne", 99 (2013) s. 19-28.

Karolewicz Grażyna, Instytut Historii Kościoła 1964-2004, Lublin 2005.

Tylus Stanisław, Wokół osoby Jubilata. Zycie i działalność naukowo-dydaktyczna Ks. Prof. Dr Hab. Marka Tomasza Zahajkiewicza, w: Historia świadectwem czasu. Księdzu profesorowi Markowi Tomaszowi Zahajkiewiczowi, red. Włodzimierz Bielak, Stanisław Tylus SAC, Lublin 2006, s. 11-27.

Żurek Waldemar W., Ośrodek Archiwów Bibliotek i Muzeów Kościelnych Katolickiego Uniwersytetu Lubelskiego Jana Pawła II w mijającym półwieczu, „Archiwa Biblioteki i Muzea Kościelne”, 86 (2007) s. 75-82.

Żurek Waldemar W., Współpraca Ośrodka Archiwów Bibliotek i Muzeów Kościelnych Katolickiego Uniwersytetu Jana Pawła II z klasztorem sióstr norbertanek w Imbramowicach, „Archiwa Biblioteki i Muzea Kościelne”, 95 (2011) s. 375-379.

Wielgus Stanisław, Na pożegnanie ks. prof. Marka Zahajkiewicza. Homilia wygłoszona podczas Mszy św. w archikatedrze lubelskie, „Przegląd Uniwersytecki”, 4-5 (156157) 2015 , s. 53-54. 


\title{
REV. PROF. DR HAB. MAREK TOMASZ ZAHAJKIEWICZ (1934-2015) -THE DIRECTOR OF THE INSTITUTE OF CHURCH ARCHIVES, LIBRARIES AND MUSEUMS AT THE CATHOLIC UNIVERSITY OF LUBLIN
}

\begin{abstract}
Summary
Rev. prof. Marek Zahajkiewicz was born on 18 February 1934 in Borysław. He died on 25 July 2015 in Lublin. In 1956, he was ordained a priest. In 1965, he began his research work at the Institute of the History of the Church at the Catholic University of Lublin. In 1967, he received his doctorate, in 1977 he became an assistant professor and in 1992 professor.

In the years 1978-2006 he ran the Department of the History of the Church in the Middle Ages at the Faculty of Theology at the Catholic University of Lublin. He was also the director of the Institute of the History of the Church at the Faculty of Theology at the Catholic University of Lublin (1983-2004).

From 1985 to 2006 he held the post of director of the Institute of Church Archives, Libraries and Museums and he was the chairman of the Journal Council of „Archiwa Biblioteki i Muzea Kościelne”. He organized, among other things, several conferences on archives, library science and church museology, and maintained high academic standards of the journal „Archiwa Biblioteki i Muzea Kościelne” after becoming a successor to Rev prof. Stanisław Librowski, the chief editor and founder of the journal.

Keywords: Rev. Marek T. Zahajkiewicz; the Institute of Church Archive, Libraries and Museums; the journal „Archiwa Biblioteki i Muzea Kościelne”; the chairman of the Journal Council, the director of the Institute of Church Archive, Libraries and Museums, the John Paul II Catholic University of Lublin
\end{abstract}

